CORRECTION

\title{
Correction: Clinical validation of an artificial intelligence-based diabetic retinopathy screening tool for a national health system
}

\author{
José Tomás Arenas-Cavalli (iD, Ignacio Abarca (D), Maximiliano Rojas-Contreras (iD, Fernando Bernuy (D) and Rodrigo Donoso (iD)
}

(C) The Author(s) 2021

Eye (2021) 35:2910; https://doi.org/10.1038/s41433-021-01690-z

Correction to: Eye https://doi.org/10.1038/s41433-020-01366-0, published online 11 January 2021

Unfortunately, an error occurred in Table 3; the formula for specificity should be read as $\mathrm{sp}=\mathrm{TN} / \mathrm{TN}+\mathrm{FP}$.

The original article has been corrected.

\begin{abstract}
(i) Open Access This article is licensed under a Creative Commons 40 International License, which permits use, sharing, adaptation, distribution and reproduction in any medium or format, as long as you give appropriate credit to the original author(s) and the source, provide a link to the Creative Commons license, and indicate if changes were made. The images or other third party material in this article are included in the article's Creative Commons license, unless indicated otherwise in a credit line to the material. If material is not included in the article's Creative Commons license and your intended use is not permitted by statutory regulation or exceeds the permitted use, you will need to obtain permission directly from the copyright holder. To view a copy of this license, visit http://creativecommons. org/licenses/by/4.0/.
\end{abstract}

(c) The Author(s) 2021 